\title{
ANOTASI BIBLIOGRAFI \\ PENGGUNAAN APLIKASI DAN MEDIA DALAM EFEKTIVITAS \\ PEMBELAJARAN SEJARAH
}

Oleh

Dywanti Oktavia Paramitha

Email : dywantioktaviaaaa@gmail.com

Program Studi Pendidikan Sejarah Fakultas Keguruan dan Ilmu Pendidikan

Universitas Lambung Mangkurat

Susanto, H., \& Akmal, H. (2018). Efektivitas Penggunaan Aplikasi Pembelajaran Berbasis

Mobile Smartphone Sebagai Media Pengenalan Sejarah Lokal Masa Revolusi Fisik Di Kalimantan Selatan Pada Siswa Sekolah Menengah Atas. Historia: Jurnal Program Studi Pendidikan Sejarah, 6(2), 197-206.

Artikel ini berisi mengenai suatu penelitian yang bertujuan untuk mengetahui apakah penggunaan aplikasi dalam pembelajaran yang diakses melalui mobile smartphone itu efektif atau tidak jika diimbangi dengan penggunaan mobile smartphone didalamnya. Terutama dalam hal media pengenalan sejarah lokal masa revolusi fisik di Kalimantan Selatan. Lalu didalam artikel ini berisi tentang bagaiamana penggunaan mobile smartphone dalam memperkenalkan suatu materi mengenai sejarah lokal agar lebih mudah dan lebih cepat lagi dalam pengenalan mengenai sejarah lokal terbut. Berdasarkan penelitian ini juga dapat disimpulkan juga bahwasanya penggunaan aplikasi dalam sistem pembelajaran berbasis mobile smartphone ini efektif jika digunakan para peserta didik disekolah menengah atas dalam melakukan kegiatan belajar mengajar agar lebih memahami suatu materi dan yang ada didalamnya terutama dalam pengenalan sejarah lokal masa revolusi fisik di Kalimantan Selatan.

Susanto, H., \& Akmal, H. (2019). Media Pembelajaran Sejarah Era Teknologi Informasi (Konsep Dasar, Prinsip Aplikatif, Dan Perancangannya). FKIP Universitas Lambung Mangkurat.

Buku ini membahas mengenai suatu inovasi tekhnologi informasi yang sekiranya dapat digunakan untuk memperbaiki kualitas dalam pembelajaran sejarah. Dalam buku juga membahas mengenai prinsip yang ada didalamnya mengenai bagaimana 
mengaplikasikan suatu media pembelajaran agar dalam penggunaan media ini berfungsi untuk memudahkan atau membantu proses pembelajaran sejarah. Dalam penelitian ini juga telah diuji coba juga dalam proses penelitiannya dan disesuaikan dengan apa yang dibutuhkan oleh mahasiswa dan mahasiswi agar dalam pembelajaran sejarah tersebut sangat efektif dalam penggunaan media tersebut didalam kegiatan yang ada .

\section{Simpulan Konseptual Anotasi Bibliografi}

Media pembelajaran dapat dikatakan sebagai alat bantu pembelajaran, yaitu segala sesuatu yang dapat digunakan untuk merangsang pikiran, perasaan, perhatian dan kemampuan atau ketrampilan peserta didik sehingga dapat mendorong terjadinya proses belajar. Dalam penggunaan aplikasi tambahan disini dapat memudahkan kegiatan belajar mengajar agar mempermudah proses didalamnya. Penggunaan media pembelajaran biasanya dipahami untuk membantu efektivitas proses belajar mengajar yang didalam kelas.

Kegiatan belajar mengajar merupakan suatu proses dimana ada interaksi timbal balik satu sama lain dalam kegiatan belajar mengajar. Lalu dalam kegiatan pembelajaran ini juga ketika diimbangi dengan penggunaan media yang baik maka keberlangsungan kegiatan belajar itu efektif, jika penggunaan media baik dalam kegiatan belajar mengajar maka akan berhasil keberlangsungan kegiatan tersebut.

Pembelajaran sejarah disini memiliki tujuan yakni untuk melahirkan generasi muda terdidik mengenai pemahaman terhadap suatu hal peristiwa yang terjadi pada masa lampau, dalam pembelajaran sejarah ini peserta didik seolah olah mebmbayangkan suatu hal yang terjadi di masa lampau sehingga muncul pemikiran peserta didik mengenai hal apa yang terjadi pada masa itu. 
